\section{Proza migracyjna: źródła i znaczenie}

Mieczysław Dąbrowski wagi na temat najnowszej literatury migracyjnej chcę zacząć od przypomnienia waźnego tekstu Haliny Filipowicz pt. „Polska literatura emigracyjna" - próba teorii'. Pojawił się w okresie dość gwałtownych rozważań nad relacją literatury krajowej i emigracyjnej. Podstawowym pytaniem autorki jest - po pierwsze - to, w jaki sposób literatura emigracyjna traktowana jest po 1989 roku w odniesieniu do literatury krajowej, co stanowi centrum, a co jest uznawane za peryferia, a przede wszystkim - jak do literatury emigracyjnej odnosi się krytyka krajowa. Udzielając odpowiedzi na te pytania, Filipowicz stwierdza, że krytyka krajowa zawsze traktowała i traktuje literaturę emigracyjną jako zewnętrzną część literatury polskiej (opozycja wnętrze - zewnętrze), że postawa home center wobec literatury emigracyjnej "zbliża się w istocie do stereotypu kolonialnego" (s. 48), gdzie literaturę emigracyjną przymierza się - „zaciekle" hierarchizującym gestem (s. 53) - do literatury krajowej,

1 H. Filipowicz "Polska literatura emigracyina" - próba teorii, przeł. K. Korżyk "Teksty Drugie" 1998 nr 3, s. 43-62. Dalej podaję strony po cytatach.

\author{
Mieczysław \\ Dąbrowski - prof. \\ drhab. w Instytucie \\ Literatury Polskiej \\ UW. Polonista \\ i komparatysta \\ Gościł z wykładami \\ na wielu uniwersy- \\ tetach europejskich, \\ trzy semestry spędzıł \\ na uniwersytetach \\ niemieckich jako \\ Gastprofessor. Ostat- \\ nio opublikował Dwa \\ wątki (2015), Literatura \\ i konteksty. Rzeczy \\ teoretyczne (2011) \\ oraz Komparatystyka \\ dia humanistów. Pod- \\ ręcznik akademicki \\ (2011; red.). Intere- \\ suje go modernizm \\ i postmodernizm, \\ pogranicza kulturowe, \\ komparatystyka \\ kulturowa, tradycja \\ zydowska w Polsce.
}


z rzadka tylko konfrontując ją z literaturą kraju goszczącego (s. 49).Zdaniem autorki wynika to stąd, że krytyce łatwiej jest przeprowadzać takie zewnętrzno-wewnętrzne porównanie, niż analizować „konfrontacje czy miłosno-nienawistne związki emigrantów z adoptowaną przez nich kulturą [...]" (s. 49). Filipowicz przytacza opisowy termin Wojciecha Wyskiela, mianowicie „współczesna literatura polska na obczyźnie”2, który ma wyminąć rozmaite rafy i obejmować najszerszy krąg zjawisk jako termin, w założeniu, neutralny politycznie, niewartościujący i pozbawiony czynnika emocjonalnego, który jednak kwituje następująco:

Termin ten, choć bardziej pojemny, zachowuje jednak, i to zupełnie nietkniętą, dawną dwoistość ojczyzny - obczyzny. (s. 51)

I na koniec zdecydowane sformułowanie autorki:

ci, którzy zostali w kraju, wciąż traktują rodaków z emigracji jako Innych. Paradoksalnie, pisarz emigracyjny jest częścią literatury polskiej, będąc z niej równocześnie - jako Inny - wykluczonym. (s. 46)

Po drugie - i ważniejsze! - Filipowicz zastanawia się nad specyfiką literatury emigracyjnej, nad jej szczególnym usytuowaniem p o $\mathrm{m}$ i ę d zy, pomiędzy tradycją krajową a językiem i literaturą kraju osiedlenia migranta, i przede wszystkim jego funkcjonowaniem w odmiennym uniwersum impulsów, problemów i wartości. Dla podkreślenia tej inności przywołuje kategorię minor literature Deleuze'a i Guattariego z ich książki Kafka: Toward a Minor Literature. Za Louisem A. Renzą formułuje znamienną tezę ogólną:

Tak więc, "literatura mniejsza” - to "literatura, która w istocie sabotuje każdy kod społeczny lub systemowy kontrolujący środki liczącej się (major) w danej chwili produkcji literackiej. (s. 58)

Wydaje się, że najnowszą literaturę migracyjną można by wpisać w koncepcję „literatury mniejszej” sensu largo. Jej domniemany „sabotaż” należałoby

2 W. Wyskiel Wprowadzenie do tematu:literatura iemigracja, w: Pisarz na obczyźnie, red. T. Bujnicki, W. Wyskiel, Ossolineum, Wrocław 1985.

3 L.A. Renza "A White Heron" and the Question of Minor Literature, University of Wisconsin Press, Madison 1984, S. 33 (cyt. za H. Filipowicz „Polska literatura emigracyjna".., s. 58-59). 
zdefiniować jako wytwarzanie takiego dyskursu literackiego, który w mniej czy bardziej wyraźny sposób przeciwstawia się dyskursowi romantycznemu, narodowo-patriotycznemu, czyli dyskursowi centrum, jaki cechował literaturę polską przez ostatnie dwa wieki, w tym także dawniejszą literaturę emigracyjną. Dyskurs romantyczny był naszym rodzimym artystycznym major kodem, systemem głównym znaków, aluzji, odniesień historycznych, kodem ponadgeneracyjnego i ponadepokowego porozumienia, kreowania znaczeń i systemu aksjologicznego, które zaczyna atakować Witold Gombrowicz już w swoich tekstach przedwojennych, ale zwłaszcza w Trans-Atlan๖ $k u^{4}, a-o d$ drugiej strony, w plebejskiej stylistyce - Marian Pankowski, o czym przekonaliśmy się (jako czytelnicy) nieco później. Wielka Emigracja, nawet jeżeli była wewnętrznie zróżnicowana w sensie wyboru języka artystycznego i dróg komunikacji z odbiorcą ${ }^{5}$, w kolejnych pokoleniach została sprowadzona do dość jednorodnego kodu znaczeniowego i tzw. stylu narodowego, który okazał się nad wyraz trwały i - wobec trudnych przypadków polskiej historii - zdolny do ciągłej aktualizacji, społecznie nośny. Ale według Deleuze'a i Guattariego w każdej kulturze/literaturze obok nurtu głównego płyną cieki mniej burzliwe, nie tak zasadnicze, chociaż płodne i ważne. Są one być może peryferyjne ${ }^{6}$, nie dość oficjalne, lecz - naznaczone czy to klasowo, czy kulturowo - modelują własną maszynerię wytwarzania znaczeń. Literatura migrancka daje swoistą odpowiedź na znamienne pytanie Deleuze'a i Guattariego, brzmiące: „Jak stać się wobec swego własnego języka nomadem i imigrantem, i cyganem?" „co dzisiaj czarni w Ameryce wyprawiają z językiem angielskim” - chodziło, oczywiście, o tworzenie swoistej subkultury językowej. Filipowicz używa tego modelu, aby uchronić literaturę emigracyjną od jałowego, choć „esencjalistycznego" kategoryzowania w kontekście tradycji rodzimej i zwrócić uwagę na wartość i jakość nowego kontekstu, w jakim ona powstaje, mianowicie

4 Zob. tekst S. Chwina dotyczący relacji obu dzieł "Trans-Atlantyk" wobec "Pana Tadeusza", "Pamiętnik Literacki" 1975 Z. 4, s. 97-121.

5 Zwracał na to uwagę już I. Matuszewski w książce Słowacki i nowa sztuka (modernizm) z 1904 roku.

6 Opozycję centrum - peryferie wykorzystuje do swoich, wprawdzie dotyczących dzieł tłumaczonych na język docelowy, ale niezmiernie instruktywnych rozważań I. Even-Zohar. Zob. tegoż Miejsce literatury tłumaczonej w polisystemie literackim, przeł. M. Heydel, w: Współczesne teorie przekładu. Antologia, red. P. Bukowski, M. Heydel, Znak, Kraków 2009, s. 197-203.

7 Cyt.za H. Filipowicz "Polska literatura emigracyina" ${ }^{\prime \prime}$, s. 60. 
kontekstu kraju osiedlenia i dyskursu wolnościowego. Ja chcę go wykorzystać dla podbudowania tezy, że literatura migracyjna nie tylko buduje swoją istotę na róźnicy kulturowej, ale także jest próbą wytworzenia jakiegoś k o n tr kodu estetycznego, w którym zawiera się polemika z polską tradycją romantyczną, ze spuścizną Mickiewicza i Pana Tadeusza i z polską kulturową utopią, która traci swoje performatywne właściwości poza granicami kraju. Jest więc świadomie tą „literaturą mniejszą", którą Filipowicz arcytrafnie, z perspektywy refleksji nad literaturą migracyjną, rozpoznaje jako „metaforę kulturowej międzystrefowości" (s. 6o), a co jest, być może, zalążkiem tworzenia tekstu, który może być ważny dla obu (wielu) kultur, gdy te spotykają się w tekście.

Międzystrefowość, a także wspomniana wcześniej w jej tekście peryferyjność ewokują kolejną kategorię, mianowicie margines, który rozumiany antropologicznie otwiera szczególne perspektywy epistemologiczne. Zauważmy, że literatura migracyjna jest ze swej natury literaturą marginesu, literaturą pogranicza, te zaś były i są rozpoznawane jako obszary z reguły twórcze i wartościowe. Charakteryzuje je bowiem wielość, spór, opozycyjność, kontestacja, wolność, co gwarantuje im pozycję swoiście uprzywilejowaną. Teksty migranckie powstają na marginesie literatury polskiej i literatury kraju osiedlenia, rodzimej i światowej. ${ }^{8}$. Wobec obu tych przestrzeni wykazują wysoki poziom krytycznego namysłu i dystansu. Margines (pogranicze) jest zatem miejscem, w którym można kreować nowy jakościowo konstrukt, nie jest on już literaturą polską w duchu major, ale jest zarazem czymś więcej niż tylko jej kontrkodem (minorliterature). Jest mianowicie miejscem wytwarzania tekstu międzykulturowego,gdzie pojawiają się ostre akcenty polemiczne wobec polskiej tradycji narodowo-historycznej i związanej z nią literatury „trubadurów”, lecz gdzie ujawniają się też światowe doświadczenia migranta, często nader krytycznie oceniane, jego podlegająca zmianom mentalnym i kulturowym podmiotowość. Niezależnie bowiem od tego, czy poszczególny migrant ocenia swój exodus z ojczyzny jako udany czy nie, żałosny czy świetny, dostrzega w każdym przypadku, że ży j e w in ny m św i e c i e, że inne kierują nim okoliczności, nawet jeżeli dobrze jeszcze rozpoznaje swoje pierwotne pragnienia. Bowiem pod wpływem tych

8 Por. b. hooks Margines jako miejsce radykalnego otwarcia, przeł. E. Domańska, "Literatura na Świecie" $2008 \mathrm{nr} 1 / 2$.

9 Aluzja do tytułu książki E. Thompson Trubadurzy imperium. Literatura rosyjska i kolonializm, przeł. B. Sierszulska, Universitas, Kraków 2000. 
nowych okoliczności, doświadczeń, bodźców zmienia się cała sfera jego psychiki, wyobrażeń, fantazji, a także ocena przeszłości.

Książka Grzegorza Kopaczewskiego pt. Global Nation. Obrazki z czasów popkultur $y^{10}$ to zapiski młodego Polaka, po studiach w Polsce, który pracuje w Londynie w usługach, najpierw sprzedając pizzę, potem książki. Mieszka w wynajmowanym mieszkaniu z kilkorgiem młodych ludzi z różnych stron świata: Amerykanin, Brad McDermont, dwie Hiszpanki Vanessa i Carol, para francusko-niemiecka Christoph i Maria), no i narrator, niejaki Daniel Berski - wszyscy na jednakowych prawach"1. Pojawi się też Fiona z Kanady, przez pewien czas dziewczyna Daniela (związki miłosne migrantów bywają zazwyczaj impulsywne, szyblie, krótkotrwałe, niezobowiązujące ${ }^{12}$ ). Ich wyposażeniem jest 85-litrowy plecak, język angielski i zdolność do życia w schroniskach. Powodem wyjazdu z ojczystych krajów są najczęściej przyczyny ekonomiczne, ale także obyczajowe, chociaż niechętnie o tym mówią ${ }^{13}$. Wszyscy pracują w usługach, najczęściej w pubach, kawiarniach, sklepach jako sprzedawcy, narzekają na swoich szefów, nie brak im jednak energii i rozrywek. „Nasze prace to minimalna płaca, maksymalna ilość godzin i zupełny brak identyfikacji z firmą" (s. 29). Ten rodzaj pracy, miejsce, czas i charakter pozostawiają wyrazisty ślad w języku:

10 G. Kopaczewski Global Nation. Obrazkiz czasów popkultury, Czarne, Wołowiec 2004. Czytamy: "U nas patriotyzmu uczy się w szkole na historii, bo dorośli myślą, że jeśli ktoś umarł na jakiejś wojnie, to ma to decydować o twojej miłości do kraju. [...] Coś ma być takie, a nie inne, bo nasi dziadowie coś zrobili. Najczęściej umierali. W ogóle u nas nikt nigdy nic nie robił poza umieraniem... [...]. Nie wiem, jak myśleć o Polsce. Lubię moje miasto, bo tam są moi przyjaciele i moja drużyna piłki nożnej, i tu też...", tamże, s. 237-238.

11 Czasami nie są to nawet osobne pokoje z łóżkami, lecz wspólne pomieszczenie z legowiskami ułożonymi wprost na podłodze, por. A. Kropiwnicki: „[...] siedem legowisk zrobionych z koców i jakichś dodatkowych szmat", Zajezdnia Londyn, Oficyna Wydawnicza Branta, Bydgoszcz-Warszawa 2007, s. 37. Ta wielokulturowość, wieloetniczność i wielorasowość należy do londyńskiej codzienności. Narrator Koziarskiego w swojej nowej pracy poznaje - oprócz szefującego Australijczyka Anthony'ego - Turka Ahmeda, Hiszpankę Sonię, Jamajczyka Markusa, Monikę z Polski, Chorwata Mariano i Roberta ze Słowacji oraz Octavię z Etiopii, Socjopata w Londynie, Prószyński i S-ka, Warszawa 2007, s. 63-64.

12 Por. „Ale każde śniadanie Magda jadła u Larsa, w małej kuchence przylegającej do małego pokoiku [...] Tydzień później Larsowi skończyło się stypendium, więc spakował walizki, oddał w Instytucie klucz od mieszkania i wrócił do Oslo, do żony i dzieci", A. KropiwnickiZajezdnia Londyn, S. 27-28.

13 "To dziwne, ale nigdy nie rozmawialiśmy o tym, dlaczego właściwie przyjechaliśmy do Londynu i co tu chcemy robić [...]", G. Kopaczewski Global Nation..., s. 64. 
Słuchaj, jak skończysz szifta, może pójdziesz z nami na drina?

- Chyba nie dam rady, bo straszne bizi mamy i już nie mam brejka, a potem długo będziemy sprzątać - odpowiedziała nowo napotkana Poleczka. - Ale jak będę miała offa, to możemy się spotkać. Mieszkam na flacie na górze. Zapytaj o Izę, a najlepiej kolnij [wyróż. - M.D.], dam ci mój numer. ${ }^{14}$

Londyn pozwala zabawić się w weekendy w każdy moźliwy sposób. Te rozrywki są dość pospolite i powszechnie praktykowane: dyskoteki, piwo, ,prochy", kino, nocne łazęgowanie, rozrywkowa "muza” - wszystko okraszone jędrnym, dosadnym, często wulgarnym językiem. Pod koniec opowieści narrator wyjeżdża z Bradem do Nowej Zelandii, tam spędza samotnie Boże Narodzenie ${ }^{15}$ na włóczędze, wycieczkach, rozmowach z przygodnymi towarzyszami podróży, po czym wraca na chwilę do Londynu, a stamtąd do Polski. Chce starać się tutaj o pracę w banku, w którym kiedyś odbywał staż.

Ta opowieść jest symptomatyczna dla nowej, „unijnej” migracji. Pokazuje ludzi bez kompleksów, znających język kraju, w którym osiadają. Wyjeżdżająca młodzież nadaje niejako na tej samej fali: znajomość klubów piłkarskich, „kultowych” filmów, zespołów muzycznych, wykonawców i piosenek, seriali telewizyjnych (np. Seksw wielkim mieście), a w wymiarze praktycznym technologia cyfrowa (laptopy, maile, SMS-y, telefonia komórkowa) stanowią podstawę bycia i porozumienia. To ich szyfr, rozpoznawcze hasła, podstawa porozumienia, namacalny efekt globalizacji ${ }^{16}$. Wszyscy funkcjonują w kulturze popularnej. „Wszystko jest popkulturą ${ }^{17}$ [...] Wszystko jest juź popularne, wszystko może być modne" (s. 79), co przynosi zyski, to najważniejszy

M. lakubowski Twarde londowanie, w: Na końcu świata napisane. Autoportret współczesnej polskiejemigracji, Videograf II, Warszawa 2008, s. 197.

15 O wieczorze wigilijnym, spędzanym w pojedynkę przy paluszkach rybnych z ryżem, mówi: "Wiem, że powinien nadejść jakiś przypływ nostalgii, melancholii, tęsknoty, smutku, ale nic takiego się nie dzieje", (s. 325, wyróż. - M.D.).

16 A. Appadurai komentuje: „Kultura popularna przekracza granice społeczne, religijne, państwowe i kontynentalne, zacierając różnice narodowe, etniczne i językowe. W największym stopniu dotyczy to kultury oferowanej przez media elektroniczne. Prawdziwym fenomenem jest pod tym względem światowa kultura młodzieżowa", w tegoż Nowoczesność bez granic. Kulturowe wymiary globalizacij, przeł. i wstęp Z. Pucek, Universitas, Kraków 2005, s. XV (ze wstępu tłumacza).

17 Por. P. Czerwiński: „My nie potrzebujemy reality shows, bo my jesteśmy koorva reality. Nam niepotrzebna jest żadna pop kultura, bo nie ma w niej kultury", Przebiegum życiae czyli kartonowa sieć, Świat Książki, Warszawa 2009. 
wyznacznik życia we współczesnym świecie. Charakterystyczne są dla tego tekstu dwie rzeczy: jako motta do poszczególnych rozdziałów pojawiają się wypowiedzi (cytaty) rówieśników, nazwanych z imienia i nazwiska, kraju pochodzenia oraz wieku (przedział wiekowy między 20 a 30 lat) z różnych stron świata ${ }^{18}$, a od czasu do czasu autor zamieszcza wiązki e-maili od i do różnych znajomych z Polski i ze świata, które są współczesnym sposobem komunikacji; tradycyjne papierowe listy nie występują. Nie ma rozmów o elementach kultury wysokiej: muzyce klasycznej, operze, wielkiej literaturze, o filozofii, o moralności. Pierwsza rzecz - motta - wskazują na znaczące przesunięcie w kulturze: liczy się nie mądrość starców, ludzi doświadczonych, lecz młodych, doświadczających właśnie i rozpoznających świat. Nikt nie jest w stanie przekazać im wiedzy, która mogłaby być użyteczna w ich życiu, poniewaź świat się zmienia z dnia na dzień; starsza generacja nie zna świata, w którym żyją młodzi, zatem wiedzę o nowych regułach gry mogą czerpać od swoich rówieśników, nabywać ją w bieżącym doświadczeniu, nie od pokolenia rodziców. Przekaz prawd życiowych przyjmuje postać horyzontalną, nie wertykalną. To bardzo zasadnicza zmiana, o której pisała kiedyś Margaret Mead, dostrzegając zaledwie zarysy zmian, które miały nastąpić w kolejnych dekadach ${ }^{19}$. Nastąpiła paradygmatyczna zmiana, która definitywnie ustaliła kierunek przekazu: w zakresie technologii, tzw. postępu cywilizacyjnego itp., zawsze już każde nowe pokolenie będzie miało więcej do powiedzenia niż pokolenie poprzednie. Otwarte zaś pozostaje pytanie o przekaz kulturowy, przekaz doświadczenia i tradycji, które wiąże się z pytaniem o charakterze bardziej fundamentalnym: na ile taki przekaz kulturowy jest młodej generacji przydatny i będzie przez nią pożądany; wydaje się, że nie jest to oczywiste samo z siebie, trzeba tu z pewnością wzmocnić rozmaite formy pedagogiki społecznej; powstaje pytanie, czy jest na to miejsce i stosowna wola. Wymiana maili z kolei ujawnia szybkość i skrótowość współczesnej korespondencji. Te elektroniczne listy, z różnych stron, ponieważ koledzy rozproszyli się po świecie, są na ogół dość pesymistyczne w ocenie charakteru i jakości życia ich nadawców. Prawie nikt nie jest zadowolony ze swojego życia, co dość symptomatyczne.

18 Np. "lezu! Telewizja mnie na to nie przygotowała" Maria Berger (24), Freiburg, Niemcy (s. 215) lub "Being local is so cool”, Katia Jensen (21), Brema, Niemcy (s. 199); „Historia już była. Dajmy szansę teraźniejszości" Christophe Laucher (26), Lyon, Francja (s. 322).

19 M. Mead Kultura i tożsamość: studium dystansu międzypokoleniowego, przeł. J. Hołówka, PWN, Warszawa 1978. 
Autor ma świadomość środowiska kulturowego, z perspektywy którego pisze swój tekst; opisując dane sytuacje i umieszczając wybrane opisy daje też wyraz swojej ocenie, odczuciom i wraźliwości. To stwarza ironiczny dystans między anegdotyczną zawartością, dość stereotypową i monotonną, a jej przesłaniem i znaczeniem. Samo znaczenie jest zaś migotliwe; mimo wyraźnej krytyki rzeczywistości, w której funkcjonuje młode pokolenie, powieść daje też wiele dowodów na to, że można w niej świetnie funkcjonować, czerpiąc tyle podniet duchowych - i takiego rodzaju - które młodym obywatelom świata najwidoczniej odpowiadają. Dobitnie ujęła to Dorota Antoniak:

Budzisz się rano i stwierdzasz, że czujesz się dobrze, a co więcej, nie tylko w swojej skórze, ale również w nowym miejscu. Niektórzy nie pasują do nowej rzeczywistości, wyjeżdżają, lecz ci, co pozostają ,prowadzą kulturoznawcze inwestygacje" [wyróż. - M.D.).Toteż zabierajcie się i jedźcie. Gdzie wam lepiej ${ }^{20}$

- kończy apelem i zachętą.

Potwierdza to także Michał Wyszowski w opowiadaniach z tomu Na lewej stronie świata ${ }^{21}$. Ta niewielka książka, napisana z werwą i talentem, zwraca bardzo często uwagę na niedopasowanie Polaków do tamtego świata. Chodzi o cechy, które swego czasu zostały ujęte w pojęcie homo sovieticus, ale też i o rozprawę z polskimi mitami narodowymi, które nie wytrzymują racjonalnej krytyki a które stanowią symboliczny bagaż każdego migranta, będący efektem domowej, szkolnej i państwowej pedagogiki.

- Męstwo, odwaga, Mickiewicz, Chopin, romantyzm, bohaterstwo, Kościuszko, Pułaski, pracowitość, fantazja, Miłosz, Gombrowicz, oddanie, wierność, Giedroyc, Jeziorański, Anders, nawet uczciwość. A teraz co? Kurwa, co? - z ogniem w oczach zerwał się na nogi. - Zobacz, jak ja wyglądam. Staliśmy się wygnanym narodem bez wyrazu, bez osobowości. Czym, kim ma być duch nowej emigracji? Cwaniactwem? Zlodziejstwem? Oszustwem? Jolantą Rutowicz? - krzyczał [...]. (s. 27)

Polska w maju 2004 roku stanęła w jednym szeregu z zamożnymi państwami Europy Zachodniej, państwami dojrzałych demokracji, co stanowiło

D. Antoniak Polski plastiknajemczy, w: Na końcu świata napisane..., s. 203. 
i stanowi do dzisiaj powód do niejakiej dumy i traktowane jest dość powszechnie jako sukces narodowy. Lecz z drugiej strony, paradoksalnie, stała się w tym samym momencie narodem pariasó $w^{22}$ Europy, niechcianych ${ }^{23}$, odrzucanych ${ }^{24}$, źle opłacanych i źle traktowanych ${ }^{25}$, czego wcześniej nigdy nie doświadczaliśmy jako naród w stopniu równie dojmującym. Książka pełna jest takich opisów i sytuacji. Napływ Polaków po 2004 roku na Wyspy okazał się iskrą wyzwalającą frustracje autochtonów, spowodowane wieloletnim napływem cudzoziemców przyjmowanych w imię politycznej poprawności i gościnności. Jeden z uczestników tragicznej kłótni w opowiadaniu Zoo wylewa naraz wszystkie stare i nowe żale. Przytaczam ten znamienny, choć długi, fragment, gdyż dobrze charakteryzuje stanowisko drugiej strony, zazwyczaj pomijane w narracjach migranckich, zajętych przede wszystkim swoimi odczuciami:

- Zamknij się - reakcja Jamiego była zdecydowana. - Myślisz, że jesteś górą, że jesteś lepszy - zaczął. - Tacy, jak ty, zawsze znajdą jakiś argument, paragraf na zasłonięcie tych słodkich gierek. Bo kryzys, bo bieda, a my wszyscy jesteśmy jedną wspólną europejską rodziną. Azjatycko-afrykańsko-europejską i naprawdę, kurwa, dużą. Musimy być dobrzy, musimy pomagać, bo przecież inni potrzebują. A kto nam pomoże?

22 „Skrojony angielską stopą i kamieniem raj, w którym nagle pojawia się słowiańska rodzina barbarzyńców. I karczuje dla siebie kawałek miejsca. Rozbija kolorowy parasol w ogródku, wystawia stół i głośno biesiaduje przed frontem wynajmowanego domu. Tak żeby wszyscy widzieli. Śpiewa, zaprasza gości, których samochody psują idealną symetrię ulicznego parkingu. Czasem kilku mężczyzn zbierze się wokół jednego z nich i długo dyskutują w tym szeleszczącym języku. Nad otwartą maską, z narzędziami i piwem w ręku. To nie może się podobać, wzbudza kolejne pomruki niezadowolenia. Nie wprost", M. Wyszowski Na lewej stronie świata, s. 34; "Bohaterstwo lotników z Bitwy o Anglię przegrywa z szopingiem. Emigracja już nie definiuje się tęsknotą do ziemi naszych dziadów i ojców", tamże, s. 152.

23 "- Łupki. Jesteśmy dla nich jak te łupiny [...]. Zaśmiecamy im ten kraj, brudzimy. Stwarzamy niepotrzebne problemy. Masa zdolnych tylko do czasowej pracy", M. Wyszowski Na lewej stronie świata, s. 26.

24 Por. tragikomiczne opowiadanie Zoo, gdzie chodzi o zapobieżenie sytuacji, w której trzy nowonarodzone tygrysy z Blackpool miałyby otrzymać, według danych plebiscytu, polskie imiona, M. Wyszowski Na lewej stronie świata, s. 87-119.

25 "Gdy spotykasz pierwszego magistra rozładowującego tiry, choć przez chwilę myślisz, że coś jest nie tak. Potem obniżasz standardy, twoja tolerancja na marnowanie życia rośnie. Wiesz też, że pytanie: „co robiłeś w Polsce? - nie zawsze jest dobrym pomysłem. To wrażliwa struna, łatwo pęka", tamże, s. 30 . 
Nielegalni imigranci z Rumunii, Polacy, gdy już zabiorą nam pracę i przejedzą wszystkie nasze pieniądze. Kiedy ostatni raz byłeś w angielskim pubie czy sklepie? Kiedy, pytam? Na mojej ulicy już nie mam takich okazji. Jest indyjskie żarcie, meczet i sklep z wyrobami z Jamajki. A ja mam w dupie wyroby z Jamajki i czarnych, którzy kręcą się pod moim domem z nożami w rękach. Gdzie jest ta potężna Wielka Brytania? W banku obsługuje mnie kobieta, która ledwo zna język, w markecie Polacy tylko kiwają głowami, gdy pytam o cenę. Bo co, tak trudno się nauczyć nawet kilku słów? Wszyscy chcą tu żyć, ale w dupie mają nasz język i to, kim jesteśmy. Chcą tylko kasy, kasy, kasy. Oczywiście, tobie to nie przeszkadza, bo żyjemy w jednym, wspólnym domu. Pierdolę taki dom i taką rodzinę. Pierdolę rząd, który zaprasza tu wszystkich, a nie dba o własnych obywateli. Rzygam polityczną poprawnością i takimi Europejczykami, jak ty. Ale ty tak nie myślisz. Masz cudowne życie, dom, pracę. Masz samochód, ciesz się, kurwa, że jeszcze go masz. Będziesz protestowal, gdy za kilka lat zabierze ci to wszystko człowiek w turbanie? Albo jakiś szalony ćpun ze strzykawką w rękach. I nic nie będziesz miał do powiedzenia, co? Słowa nie piśniesz, gdy Turek z kolegami przelecą twoją dorastającą córkę? Bo tak trzeba, bo Anglia to otwarty kraj wielkich możliwości dla całego jebanego świata. Prawda, doktorze Parr? (s. 116-117) ${ }^{26}$

Życie w społeczeństwach multikulturowych ${ }^{27}$ wyczula także na konflikty pojawiające się nawet między najbliższymi sąsiadami z ulicy, miasta, kraju. P a r a doksalnie, i jednocześnie wyczula na różnice i łatwo godzi się na ich niwelowanie, sprowadzanie do zera. Rejony, dajmyna

26 Por. A. Kropiwnicki: „- Dlaczego? Dlatego, że Polacy, tacy jak ty, odebrali mi robotę - powiedział wrogo. - Polacy i reszta tej hołoty ze Wschodu. Pracowałem na budowie i miałem dobrze, aż przyszyliście wy i nie mam co ze sobą zrobić. Dlaczego się stąd nie wyniesiecie, wszyscy?", w: tegoż Zajezdnia Londyn, s. 43; Por. D. Koziarki: „Skąd tu przyjechałeś - z Polski, co? Po co otwieraliśmy te granice na Europę Wschodnią, po to, żeby nas zalało niekulturalne gówno? - piekliła się. - I kto to mówi! - Poczułem, jak z nerwów pulsują mi skronie. - Przynajmniej jestem na swoim kontynencie, w przeciwieństwie do ciebie!", tegoż Socjopata w Londynie, s. 48. Narrator odzywa się w ten rasistowski i postkolonialny sposób do swojej sąsiadki Brendy, Murzynki.

"Zaklęte rewiry [pomieszczenia kuchenne, magazyny - przyp. M.D.] portowej knajpy pełne są ludzi, którzy przybyli tu z różnych stron po to, by zmienić swój los, uciec przed biedą, coś sobie udowodnić, zdobyć świat. Węgrzy, Hindusi, Polacy, Banglijczycy, Słowacy, Birmańczycy, Litwini i Łotysze ocierają się codziennie o siebie, rozmawiają, kłócą się, czasem powarkują w swoich egzotycznych językach, co przyprawia irlandzkich menadżerów o gęsią skórkę", Ł. Ślipko Pokój zwidokiem na Dunnes Stores, RB, Opole 2011, s. 8. 
to, dalekiego Wschodu czy Afryki są dla przeciętnego Europejczyka the same (i odwrotnie!), choć między sobą, w sąsiedzkim dyskursie jesteśmy w stanie wskazać dziesiątki odmienności. Działa tu powszechne prawo stereotypizacji, uproszczonego, metonimicznego rozumowania, w którym pod uwagę bierze się zwykle jeden wyznacznik (wyznanie, kolor skóry, obyczaj, typ prawa) i buduje na nim ogólne wyobrażenie, zapominając o wielu innych, subtelniejszych, bardziej indywidualnych różnicach. Działa prawo wielkiej liczby i prawo do uproszczenia.

Irlandzki pub, w którym pracują słabo mówiący po angielsku imigranci $\mathrm{z}$ różnych stron świata, to pub absurdalny. Produkt lotniskowy, produkt rozumu korporacyjnego. Irlandzki pub, w którym pracują słabo mówiący po angielsku... Schronili się pod parasol dobrobytu, zostawiając za sobą zapadłe wsie, dziurawe drogi i zardzewiałe autobusy. Wpuszczono ich do kryształowego pałacu, ale nawet $w$ tym pałacu nie są wolni od trosk, a wysoki standard życia materialnego okupują byciem „innymi", "zewnętrznymi proletariuszami”, pozbawionymi silnego, giętkiego języka, którego każdy człowiek potrzebuje, aby wyrażać siebie, walczyć o swoje prawa, komunikować się z innymi. (s. 21)

Wśród tekstów polsko-irlandzkich wyróżnia się powieść Piotra Czerwińskiego pod tytułem Przebiegum życiae (kalka Curriculum vitae). To określenie będzie motywem przewodnim opowieści, bowiem bohaterowie wysyłają setki życiorysów do różnych firm, nie otrzymując na ogół żadnej odpowiedzi. Co więcej, okazuje się, że te CV, zrazu ujmujące prawdziwe i pełne doświadczenie oraz wykształcenie aplikującego Polaka, w kolejnych wersjach są upraszczane i skracane, ponieważ tylko takie mają szanse na zatrzymanie uwagi odpowiedniego urzędu czy decydenta. Polacy są, jak się tam mówi, gównianym narodem do gównianej pracy, więc takie też muszą być ich „przebiegi życia”. Ta znakomicie napisana, choć zrazu lekko irytująca swoją stylistyką książka, jest kopalnią wiedzy o losach polskich migrantów zarobkowych, o irlandzkiej mentalności, pogodzie ${ }^{\mathbf{2 8}}$, mieszkaniach, urządzeniu łazienek, języku angielskim, kulturze kulinarnej, totalnym chaosie ${ }^{29}$ etc. Bohaterami są niejaki

28 „W krainie bajobongo nie istniało pojęcie pogody. Na zmianę padało i świeciło, padało i świeciło, świeciło i padało, sześć razy”; "Nie ma też pór roku w tradycyinym znaczeniu, ponieważ wszystkie cztery występują codziennie", P. Czerwiński Przebiegum życiae..., S. 104 i 133.

29 "Gustaw właśnie wrócił ze sklepu dla Polaków, w którym Rosjanie sprzedają litewskie żarcie [...]", P. Czerwiński Przebiegum życiae..., s. 134. 
Gustaw i Konrad (imiona w polskiej kulturze znaczące!), którzy znaleźli się na dublińskim bruku w odstępie pół roku i których, zatrudnionych jako śmieciarze, los zetknął w pewnej fabryce i w wynajmowanym wspólnie mieszkaniu.

Środowisko Polaków opisane w powieści to ludzie z dyplomami uniwersyteckimi, posługujący się lepiej lub gorzej językiem angielskim, Gustaw np. używa pięknego british english, który jego irlandzcy rozmówcy z trudem rozumieją ${ }^{30}$. Czerwiński wielokrotnie podkreśla, że język angielski, w wersji irlandzkiej, jest potwornie wykoślawiony, niepoprawny gramatycznie i fonetycznie, wypowiedzi „Iroli”, często zapisywane w tej powieści, brzmią karykaturalnie i niemal nieprawdopodobnie (potwierdza się przekonanie, że najczystszy angielski zachowywany jest obecnie w byłych koloniach brytyjskich, zwłaszcza w Indiach). Dodać trzeba, że są to dyplomy magisterskie (a nawet doktorskie) z tzw. nauk społecznych, Konrad jest np. socjologiem, dużo jest politologów (jest teź teolog), którzy w Polsce nie mogli znaleźć zatrudnienia zgodnego z wykształceniem. Nie znaleźli go tym bardziej w Irlandii. Ludzie, którym się na tym rynku powiodło, mieli konkretne wykształcenie (lekarze, architekci, informatycy ${ }^{31}$ ). Pierwsza część książki jest opisem historii Gustawa, czterdziestoletniego „pryka”, jak go nazywa Konrad (sam ma lat dwadzieścia sześć), znakomicie wykształconego ekonomisty, pracującego w ciągu piętnastu lat, jakie upłynęły od studiów w warszawskiej Szkole Głównej Handlowej, w kilku międzynarodowych korporacjach na wysokich stanowiskach. Pewnego pięknego dnia „wygryzł” go ze „stołka” "młody wilk”, podrzucając mu i upubliczniając e-mail zawierający treści niezgodne z linią postępowania korporacji; nie pomogły tłumaczenia, Gustaw został zwolniony. Nie może znaleźć nowej pracy, opuszcza go żona, zabierając dzieci, kończą się oszczędności, musi opuścić mieszkanie zgodnie z umową rozwodową, więc w wigilię Bożego Narodzenia kupuje bilet do Dublina. Bilet w jedną stronę. Pod koniec powieści wyrzeka się swojej polskości i Polski, przestaje je traktować jako gwaranty i wyznaczniki tożsamości i zarazem wartości do czegokolwiek zobowiązujące. W Dublinie przeszedł cierniową drogę upokorzenia, rozsyłając i roznosząc po sklepach i instytucjach swoje "przebiegum życiae", najpierw w pełnej wersji na czele z dyplomem MBA, potem w skróconej, wreszcie

30 "[...] jego angielski był naprawdę perfekcyjny. Słuchając go, nikt by nie dał wiary, że ten człowiek pochodzi z Bulandy", P. Czerwiński Przebiegum życiae..., s. 185.

31

O takich czytamy: „Niektórzy Polacy są szczęściarzami i też pracują w tych biznes parkach, i też, of course, są wannable locals. To są ci Polacy, którzy udają, że cię nie rozumieją, i przestają mówić po polsku, kiedy podchodzisz bliżej", P. Czerwiński Przebiegum życiae..., s. 183. 
w prymitywnej, w której była tylko informacja, że ma maturę i prawo jaz$d^{32}$. Ale i tak nie było dla niego pracy. Zaproponował mu ją Konrad, spotkany przypadkowo w pubie, potem jego najlepszy przyjaciel, ponieważ akurat jego partner w pracy uległ wypadkowi i trzeba było szybko znaleźć jakiegoś Polaka na jego miejsce. Śmieci nie mogły czekać33.

Tu zaczyna się druga część powieści, w której losy Gustawa i Konrada są ściśle ze sobą splecione. Praca polegała na usuwaniu setek kartonowych pudeł z jakąś zawartością, wrzucaniem ich do olbrzymiej mielarki, sprzątaniu hal fabrycznych, wybieraniu z trawy tysięcy niedopałków porzuconych tam przez robotników w czasie przerw w $^{34}$ itp. Gustaw pisze w tajemnicy scenariusz na temat ich życia, który próbuje - bez powodzenia, niestety - sprzedać jakiejś wytwórni filmowej3. W końcu któregoś dnia nie wraca do wspólnego

32 "Ludzie w tych job agencjach mają często alergię na szkolnictwo wyższe, więc please, nie każcie im kichać jeszcze więcej. Bądźcie ludźmi, wykasujcie magistra. A jak trafił się wam doktorat, zapomnijcie o tym, że coś takiego w ogóle miało miejsce, dla własnego dobra. Oni nie to mają na myśli, kiedy mówię «degrees»; to jest o lata świetlne za dużo degrees na tutejsze realia. Zawsze chcieliście poczuć się młodo, więc there you go, cofnijcie się do matury. Spodoba im się takie przebiegum życiae i załatwią wam kilka interviews. Powiedzą wam, że rokujecie nadzieje, by rozwijać swoje umiejętności w data entry albo jako sekretarka, or something, a któregoś dnia, jeśli będziecie pracować wystarczająco ciężko, zdobędziecie niezbędne irlandzkie doświadczenie, by zostać urzędnikiem lub kasjerem, and you know, odniesiecie wielki sukces", P. Czerwiński Przebiegum życiae..., s. 117-118. Por. także s. 127.

33 „A ponadto jesteśmy jedynymi śmieciarzami w historii świata, którzy mają dyplomy uniwersytetu”, P. Czerwiński Przebiegum życiae..., s. 170. Por. P. Kępski: „Co za ironia, że ja, urodzony w tamtym komunistycznym raju, po latach jadę żebrać o byle jaką pracę u dawnych wyzyskiwaczy, zachodnich imperialistów, którzy stali się naszymi braćmi we wspólnej Europie. Od dziesięciu miesięcy sprzątam kible, myję podłogi, okna, wanny i kafelki w łazience i ślinię się na myśl o zatrutych, słodkich funtach, które co miesiąc lądują na moim koncie". I dalej: „Dość szybko zrozumiałem, że mimo skończonych studiów dla tubylców jestem tylko kolejnym napływowym półanalfabetą, któremu wydaje się, że zna angielski [...] który nigdy nie dostanie takiej samej pracy i płacy jak ci, co się tutaj urodzili, mają dyplomy miejscowych uniwersytetów i biegle znają angielski [...]", tegoż Single, Jirafa Roja, Warszawa 2009, s. 12, 17, 53 .

34 "I te przygłupie skurwle, oparte o ścianę fabryki pod zadaszeniem, stoją nad nim [Gustawem - przyp. M.D.], palą te zasrane cigarety i rzucają mu je pod nogi, a właściwie pod ręce [...]. I wyglądał tak idiotycznie i bezradnie na tym trawniku, w tym płaszczu, kaszląc na tych klęczkach, i wydawał się taki nieporadny i prostoduszny, true, true, jak dobre dziecko", P. Czerwiński Przebiegum życiae.., s. 235.

35 Wyimekz jego listu do pewnej Broadcasting and Television Production: „Wybrałem formę scenariusza, ponieważ według mnie film jest obecnie najbardziej wpływowym medium komunikacyjnym, zwłaszcza w przypadku projektu takiego jak ten, gdzie jedną z głównych grup docelowych tego przedsięwzięcia mogą okazać się polscy emigranci w Irlandii (i ogólnie na świecie). Zdecy- 
domu, policja go nie odnajduje, zabiera tylko jego rzeczy, by przekazać je ambasadzie Bulandy. Polska bowiem nazywana jest w powieści Bulandą, co ma zapewne sens degradacji połączonej z egzotyzacją (por. A. Jarry Ubu Król, czyli Polacy, 1896). Irlandia zaś nazywana jest krajem bajobongo lub milkandhoney paradies. Opowieść wykorzystuje bardzo chętnie popularne slangowe zwroty angielskie (których słowniczek umieszcza autor na końcu książki), co sprawia, że tekst w całości nacechowany jest obcością, autorskim, narracyjnym dystansem. Ale pozwala też na taki rodzaj opowiadania, który czasami jest na pograniczu narracji nieporadnej, kiczowatej, prymitywnej, a jednak służącej dobrze wytworzeniu dyskursu nieporozumienia, żalu, pretensji, rozpaczy, degradacji, upokorzenia, ostatecznie - krytyki i dekonstrukcji. Wszystkie te uczucia i odczucia są udziałem naszych protagonistów, w przypadku Gustawa pogłębionych jeszcze przez absolutny brak kontaktu z córkami i byłą żoną; kierowane do nich e-maile wracają jako nieodebrane, adresy zostały zmienione. Czerwińskiemu udało się opisać jego los w sposób pełny, głęboki, czuły i szorstki zarazem, wydobywając z niego przeraźliwy dramat inteligentnego, wraźliwego i wykształconego człowieka, którego pochłonął i zniszczył świat brutalnego kapitalizmu. Gustaw zniknął, zostawiając Konradowi ${ }^{36}$ swój laptop ze scenariuszem i tysiącami e-maili z poprzedniego życia oraz list pożegnalny. Jednakże zakończenie powieści jest zastanawiające.

Konrad otrzymuje nieoczekiwanie list z firmy, do której kiedyś napisał, z zaproszeniem do natychmiastowego rozpoczęcia pracy jako ,assistent" w dziale business development, na osobiste zapotrzebowanie głównego menedżera. Konrad jedzie na rozmowę, ale finałem powieści nie jest realna rozmowa, lecz fragment scenariusza zapisujący tę właśnie sytuację: garniturowy strój, krawat „starego", autobus, droga do firmy. Kto i kiedy napisal tę scenę? Czy należy przypuszczać, że Gustaw, odrzuciwszy swoją polskość

\footnotetext{
dowana większość z nich nie opanowała języka angielskiego w stopniu wystarczającym, by przeczytać tę historię w formie książkowej, stąd próbę dotarcia do tej społeczności poprzez formy audiowizualne uważam za najbardziej wskazaną. Obecnie w Irlandii mieszka 300000 Polaków, kolejne 500000 przebywa w Wielkiej Brytanii, co tworzy olbrzymi rynek dla projektu takiego jak ten”, P. Czerwiński Przebjegum życiae..., s. 231 (w oryginale kursywa); Por. „Polska jako kraj stanie się niedługo wirtualny. Wszyscy spierdolimy, ostatni zgasi światło", tamże, s. 265. 
i figurę Polaka, postanowił zacząć życie od nowa jako nie-Polak i np. udało mu się zająć odpowiedzialne stanowisko w tejże nowej firmie, zgodne z jego wykształceniem i kwalifikacjami? I czy ów list zapraszający Konrada nie był przypadkiem jego dyspozycją i odpowiedzią na „prawdziwą przyjaźn”, jaką Konrad mu ofiarowat?

Powieść nie rozstrzyga tych kwestii, zakończenie jest otwarte i niejednoznaczne. Byłażby to jakaś sugestia pozytywnego zwrotu w losach tych ciężko doświadczonych osób? Być może. I niechby tak było, ponieważ miara upokorzenia i cierpienia została tu wyczerpana do cna. A przynajmniej udało się to autorowi skutecznie zasugerować.

Powieść Czerwińskiego, jak wszystkie inne teksty tu przywołane, spełnia dokładnie warunek, jaki ustanawia Michael Seidel w książce Exile and the Narrative Imagination, zwracając szczególnie uwagę na „literackie reprezentacje wygnania, szczególnie takie, w których wygnanie czy ekspatriacja wysuwa się na pierwszy plan jako działanie narracyjne" ${ }^{37}$. Piotr Kępski wprowadza tu jeszcze jeden istotny element: zapóźnienie cywilizacyjno-obyczajowo- prawne Polski wobec zachodniego świata, czytelne w naszym języku, w publicznym dyskursie. W trakcie rozmowy z ojcem nachodzi go znamienna refleksja dotycząca różnicy między Londynem a jego podwarszawską mieściną:

Kto zdołałby opisać to wszystko w tutejszym dialekcie, w którym słowa takie jak metropolia, melting-pot, geje i lesbijki, Soho, Chinatown, political correctness, City, positive discrimination, Heathrow brzmiały niedorzecznie, obco, wręcz śmiesznie. ${ }^{38}$

Tu wracam do koncepcji minor literature, a właściwie opozycji major/minor literature. Opozycyjność tej literatury mniejszej wobec więsszej literatury polskiej, literatury narodowej, centralnej, wzorcowej itp. polega głównie na radykalnym odrzuceniu romantycznego wzorca tekstu, krytyce historii Polski i jej współczesności, radykalnie namiętnej polemice z kultem narodowego cierpiętnictwa, mesjanizmu, haseł poświęcenia dla ojczyzny, podporządkowania

37 Cyt za H. Filipowicz "Polska literatura emigracyina"..., s. 57.

38 P. Kępski Single, s. 58. Por. scenęz z powieści D. Koziarskiego, gdy bohater podejrzewa, że jeden z kolegów z pracy jest gejem. Sonia, Hiszpanka, odpowiada: „- To chyba oczywiste! - Zaśmiała się szyderczo, łapiąc w końcu, co mam na myśli. - To widać w każdym jego geście i ruchu, nie? - Ale on ma obrączkę! - A co? Myślisz, że... aaach, zapomniałam, że jesteś z Polski. [wyróż. M.D.] - Nie przestawała się śmiać [...]", tegoż Socjopata w Londynie, s. 66. 
jednostki społeczności itp. Patronuje temu procesowi Gombrowicz ze swoją opozycją ojczyzna/synczyzna, patronują Bobkowski z Pankowskim i zapewne wielu innych jeszcze pisarzy, którzy od początku II Rzeczypospolitej próbowali zmienić wektor polskiej mowy literackiej ${ }^{39}$. Model romantycznego myślenia i pisania był jednak i jest wciąż wpływowy, anektuje stosunkowo nowe dyskursy naukowe (np. postkolonialny), anektuje, poniewaź jest łatwy, od dawna skodyfikowany, dobrze oswojony i operuje rozpoznawalnymi znakami. Nowsza literatura migracyjna dąży w kierunku ukształtowania języka odmiennego, wciąż wprawdzie zależnego od modelu romantycznego, przynajmniej w pierwszej fazie, ale wyraźnie wobec niego polemicznego, próbującego podjąć dzieło emancypacji, oderwania świadomości Polaka poza krajem (zresztą młoda literatura pisana w kraju zdradza podobny kierunek) od tego paradygmatu i skierowania jego wyobraźni językowej i świadomości na kwestie uniwersalne. Gombrowiczowska metafora ojczyzny tu znajduje swoje twarde uzasadnienie; przytaczałem formułowane pod adresem tejże „ojczyzny” zarzuty, głównie takie, że masy ludzi wyrzuciła poza burtę kraju, skazała na migracyjny los, nierzadko upokorzenie, większe niż te, których doświadczały wcześniejsze pokolenia emigrantów, ponieważ współczesny świat pełen jest ludzi bezwzględnie poszukujących nowej ojczyzny, a głównie pracy. Znamienne są odpowiednie fragmenty powieści Czerwińskiego.

- W takim razie jakie prace są dla nas w tym kraju?

- Jak to jakie? Gówniane.

- Z całym szacunkiem, przyjacielu, gówniane prace są dla gównianych ludzi.

- My jesteśmy gównianymi ludźmi, szanowny kolego. My. [...] (s. 87; rozmowa Gustawa z Bartoszem, eks-teologiem z Lublina);

- To już nie jest moja ojczyzna. - Był wystraszony jak uczniak. - I nie mój interes. Żeby się wdawać w bójki w imieniu kraju, który mnie już nie obchodzi [...]

- Już ci powiedziałem. Polska to już nie jest moja ojczyzna. My już nie mamy ojczyzny. (s. 287-288)

Jest też zjadliwą krytyką dyskursu europejskiego. O swoich kolegach uniwersyteckich (a obecnie współlokatorach z sąsiedniego pokoju) mówi jako o naiwniakach, którzy 
Zawsze wygadywali te modne bullshity o Unii Europejskiej i jak to będzie wspaniale, kiedy wreszcie do niej wejdziemy [...] Miałem pierdolisty fun, kiedy spotkałem całą tę paczkę w Dublinie, już bez tych modnych fancy ciuchów i bez modnych teoryjek o Europie. (s. 219-220)

Jest to więc nie tylko krytyka tradycji polskiej, która jest raczej balastem niż pomocą w życiu migranta, ale także utopii europejskiej, która głosiła powszechną równość, zgodę i dobrobyt. Można przyjąć, że w s pół c ze s ny człowiek nie ma swojego miejsca, ale tekst je posiada. Widać to bardzo dobrze na powyższych przykładach ${ }^{40}$. Narratorzy-bohaterowie tych opowieści dziś są w Irlandii czy Anglii, jutro mogą być w Polsce lub nawet w Nowej Zelandii, ale ich teksty pozostaną mocno związane z konkretnym miejscem i czasem, który je pisał. To jedna z żywotnych cech poetyki tej literatury, „poetyki zagranicy”. Autorka tego określenia kładzie nacisk na perspektywę opisu, zawsze jakby z drugiego brzegu ${ }^{41}$. Ale dodałbym uwagę o charakterze komparatystycznym, przywołując kategorię metaoglądu. Chodzi przecież o to, że pisarz/narrator/bohater (bardzo często w jednej osobie) traktuje opisywany materiał antropologiczny porównawczo, musi więc zająć pozycję p o n a d, osadzoną na podstawie tertium comparationis, która gwarantuje mu takie spojrzenie. Nie musi ona być perspektywą wyłączną, ale jest/bywa dominującą. Czapliński wymienia tu jeszcze: „sieć globalnych zależności”, poszukiwanie związków między „formami mobilności i formami artykulacji", co oznacza dla badacza konieczność uruchomienia perspektywy transdyscyplinarnej, wreszcie jest to „odsyłanie do autokreacyjnego charakteru samej narracji” "42. Zasada autokreacyjności realizuje się tu najczęściej na dwa sposoby: jako podmiot sylleptyczny lub/i jako autofikcja. Z podmiotem sylleptycznym jesteśmy bardzo dobrze oswojeni, zarówno badacze, jak i autorzy, toteź nikogo nie dziwi quasi-autobiograficzny charakter tej literatury.

W tę literaturę wpisana jest niewygoda, jaka wynika z konieczności zmagania się z polską mentalnością i polską tradycją poza jej granicami, wobec

40 Pewnym wyjątkiem jest twórczość migracyjna N. Goerke, której minifabuły nie mają umiejscowienia, a jeżeli już, to w snach lub przestrzeniach imaginacyjnych.

41 M. Zduniak-Wiktorowicz "W szpagacie". Pisarz między Polskq a Niemcami, w: Poetyka migracji. Doświadczenie granic w literaturze przełomu XX i XXI wieku, red. P. Czapliński, R. Makarska, M. Tomczok, Wydawnictwo UŚ, Katowice 2013, s. 223-235, tu: s. 234.

42 P. Czapliński, Kontury mobilności, w: Poetyka migracji, s. 41. 
obcych żywiołów ${ }^{43}$. Literatura polska (w wersji major) jest przecież literaturą zasiedziałości, komfortu znajomych twarzy, dobrze przyswojonych reguł gry społecznej, materialnych podstaw bycia i znaków symbolicznych. Dwuznaczną opinię formułuje na ich temat Braidotti:

Proszę zwrócić uwagę, że bardzo uregulowani, zakotwiczeni, osiadli ludzie należą do najmniej empatycznych, najmniej emocjonalnych, najbardziej świadomie „apolitycznych”. (s. 65)

Braidotti w Podmiotach nomadycznych dokonuje rzeczy zarazem karkołomnej i wspaniałej: mianowicie odczarowuje kategorię nomady, odbiera jej negatywny czy, przynajmniej, lekko pesymistyczny i nostalgiczny sens, wcześniej tak silnie ją charakteryzujący. Nomadyczność jest zdaniem badaczki stanem, jeśli nie pożądanym, to takim, który w zupełnie podstawowym sensie określa naszą współczesną kondycję, powinien więc być akceptowany i pozytywnie waloryzowany, gdyż jest stanem otwarcia umysłu i emocji na nowe doświadczenia, na Innego/Obcego i na to, co nowe. Nomada jest cool, jest sexy.

Mówi o nich w swojej opowieści Kopaczewski, gdy opisuje swój wieczór wigilijny w Nowej Zelandii. Z jednej strony wymienia zespół nostalgicznych gestów - znaków, które powinny zostać wykonane w takim czasie, z drugiej zauważa, że można je bez strat tożsamościowych ominąć, uwalniając się od ich zniewalającej siły. Jest to znak swoistej rebelii wobec tradycji, zaznaczanie osobistego dystansu wobec narodowego centrum, rodzaj kulturowej nielojalności.

Książki tu analizowane i wiele innych wskazują też na większą i swoiście teraz rozumianą tożsamość. Już wcześniej odnotowałem, że nie jest ona monolityczna, lecz wielowarstwowa i labilna, ale z perspektywy kształtującego się wzorca (stylu) tej minor literatury polskiej trzeba zauwaźyć jej aspekt najzupełniej podstawowy: ma ona podwójny wektor, kieruje uwagę podmiotu w przeszłość i przyszłość. A nawet dokładniej: toźsamość wynika z przeszłości z e względu na przyszłość. Podmiot migracyjny (czy nomadyczny) przywołuje swoją przeszłość, aby rozpoznać jej strukturę i zweryfikować twardy, w trójkątach sprzedawany. Albo takie batony. Baton lędruś, baton Pawełek. Albo wątrobianka. Flaki. Salceson z rybim oczkiem i włosem knura. Madame Pasztetowa. Pasztet. Mazowiecki. I inni. Brak. Straszna, straszna tęsknota [pisownia oryginalna - przyp. M.D.]", w tejże, opowiadanie tytułowe, w: Księga Pasztetów, Obserwator, Poznań 1997, s. 61-69, tu: s. 66. 
wartość ze względu na to, jak postrzega projekt swojej przyszłości. Przeszłość, to pełen zestaw narodowego doświadczenia, które wynosi się z domu, ze szkoły, z publicznego dyskursu, z pedagogiki społecznej. Status przeszłości w jego świadomości z pewnością zajmuje poważniejsze miejsce niż u jakiegokolwiek człowieka zasiedziałego. W narracjach migracyjnych zajmuje wiele miejsca, chociaz, podkreślmy to raz jeszcze, nie występuje w funkcji nostalgicznej i kojącej (bo te można łatwo uśmierzyć pobytem w ojczyźnie pierwotnej), lecz raczej dekonstrukcyjnej, krytycznej, rewolucyjnej. W małych prozach Nataszy Goerke pojawia się np. nieoczekiwanie, pośród informacji o innych kulturach i systemach wartości, nomadycznym stylu życia, opowieściach o świecie i „nie z tego świata” ${ }^{44}$, niby niewinnie, lecz w gruncie rzeczy zjadliwie. Dla niej nic nie jest obce lub może raczej: wszystko jest obce w równym stopniu, wszystko na dystans, także jej własna, polska tradycja, kultura, obyczaj, zachowania. Bohater/narrator akceptuje każdą kulturę, ale nie odnajduje się w żadnej, z żadną się nie identyfikuje. Właśnie dlatego, że w kosmopolitycznym kontekście rodzime znaki wyobcowują się ze swego naturalnego sensu, domagają się czytania według innego kodu. Oznacza to także np. obecność obcego języka, wobec którego przejawia się zarazem naturalny opór i ciekawość (pomijając pragmatyczną konieczność), przykładem takiego tekstu jest właśnie powieść Czerwińskiego pt. Przebiegum życiae czyli kartonowa sieć. Autor często wplata w swoją narrację zwroty angielskie, niekiedy podwajając wypowiedź, niekiedy zastępując angielskim odpowiednie wyrażenie polskie ${ }^{45}$. W dawnych wiekach nazywano takie zachowanie makaronizowaniem ${ }^{46}$, tu jednak chodzi o wy twarzanie nowej formuły tekstu,

44 Por. „Podczas gdy pan Zero rozprawiał się z komputerowym językiem lava i wyśpiewywał po nocach Polonez Ogińskiego, pani Zero pisała opowiadania. Opowiadania te były bardzo krótkie, pozbawione akcji i, jak powiadano, niestrawne", N. Goerke, opowiadanie tytułowe w zbiorze Pożegnanie plazmy, Czarne, Wołowiec 1999, s. 23-28, tu: s. 27.

45 A. Palej pokazuje to zjawisko na przykładzie pisanych po niemiecku tekstów polskich migrantów, gdzie pojawiają się liczne cytaty z języka polskiego, zob. tejże Fließende Identitäten die deutsch-polnischen Autoren mit Migrationshintergrund nach 1989, rozdz. 11. Zu Hause in der deutschen Sprache: Mehsprachigkeit und sprachliche Kreativität, Wydawnictwo UJ, Kraków 2015, S. 237-261.

46 Por. na ten temat wypowiedź M. Danilewicz-Zielińskiej: „Literacka polszczyzna Emigracji unika na ogół makaronizmów, czego świadectwem jest znikoma liczba neologizmów typu «kafejka» czy «flat». Złowrogi przykład języka amerykańskiej emigracji zarobkowej odegrał tu pewną rolę, powstrzymując ciągotki z wczesnego okresu, gdy do «fasonu» należało popisywanie się świeżej daty znajomością języków krajów osiedlenia", tejże lęzyk twórczości, w: Szkice o literaturze emigracyinej, Ossolineum, Wrocław 1999 (wyd. 2, rozszerzone), s. 353-358, tu: s. 356. 
tekstuminor, który stoi na pograniczu kodu rodzimego i kodu obcego, czy kodu Innego, obrysowując tym samym ramy dyskursu migracyjnego, niewątpliwie innowacyjnego, do którego należy istnienie w dwu (czy kilku) językach, a także przestrzeniach, równocześnie. „Pisanie [migracyjne - przyp. M.D.] to nie tylko proces stałego tłumaczenia, ale także następująca po sobie adaptacja do różnych rzeczywistości kulturowych" ${ }^{47}$. W tym uwikłaniu tożsamość nigdy nie okaże się jednoznaczna i stabilna, ani ta z przeszłości (bo nagle stawiane są jej nowe, czasami obce pytania, które ją destabilizują), ani ta z przyszłości (ponieważ oparta jest na niepewnym bagażu przeszłości i niezdefiniowanych przesłankach przyszłości). Rozdroże i niejasność. Depresja i bunt.

Historia trwa, doświad czenie migracji pisze się każdego dnia...

\section{Abstract}

\section{Mieczysław Dąbrowski}

UNIVERSITY OFWARSAW

Migrant Prose: Sources and Meaning

Dąbrowski examines migrant literature in the context of Gilles Deleuze and Félix Guattari's notion of major/minor literature and the key Polish tradition which is Romanticism. Migrant literature, created as a polemic with the Romantic or national code and in the context of the experience of the host country's Otherness or Foreignness, can be seen as a contemporary form of Polish'minor literature'.

\section{Keywords}

migrant literature, major/minor literature, national discourse, difference

47 R. Braidotti Podmioty nomadyczne, przeł. A. Derra, Wydawnictwa Akademickie i Profesjonalne, Warszawa 2009, S. 42 . 